\title{
Drivers of Peru's Equilibrium Real Exchange Rate: Is the Nuevo Sol a Commodity Currency?
}




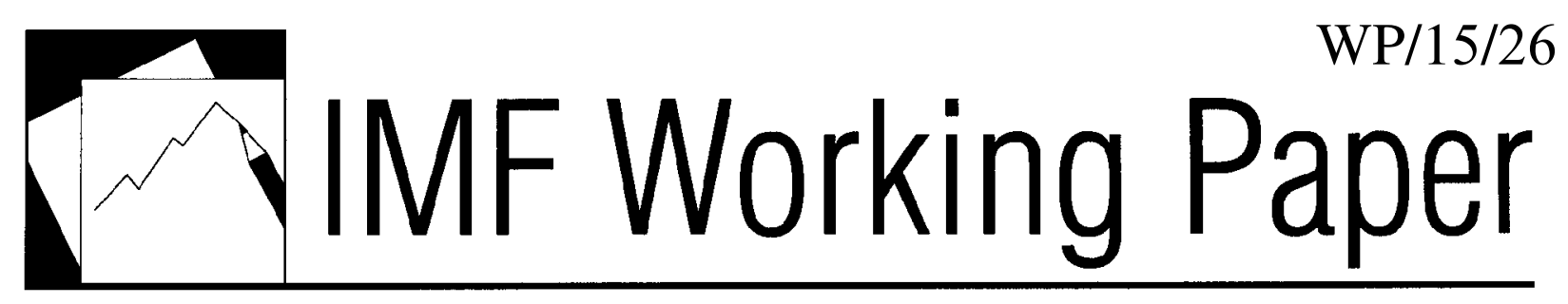

Drivers of Peru's Equilibrium Real Exchange
Rate: Is the Nuevo Sol a Commodity Currency?

Melesse Tashu 


\title{
IMF Working Paper
}

Western Hemisphere Department

\section{Drivers of Peru's Equilibrium Real Exchange Rate: Is the Nuevo Sol a Commodity Currency?}

\section{Prepared by Melesse Tashu*}

Authorized for distribution by Alejandro Santos

February 2015

\section{This Working Paper should not be reported as representing the views of the IMF.} The views expressed in this Working Paper are those of the author(s) and do not necessarily represent those of the IMF or IMF policy. Working Papers describe research in progress by the author(s) and are published to elicit comments and to further debate.

\begin{abstract}
This paper tests the hypothesis of 'commodity currency' on the nuevo sol and, more generally, identifies the drivers of Peru's equilibrium real exchange rate using a cointegration analysis. The results show that export commodity prices do not have a statistically significant impact on Peru's real effective exchange rate, suggesting that the nuevo sol is not a commodity currency. The paper provides empirical evidence that large profit repatriation and foreign exchange intervention have effectivelly insulated Peru's real exchange rate from the impact of commodity price shocks. Peru's equilibrium real exchange rate is found to be driven mostly by productivity and government consumption.
\end{abstract}

JEL Classification Numbers: F31, F41

Keywords: Real exchange rate, Commodity prices, Foreign exchange intervention Author’s E-Mail Address: mtashu@imf.org

\footnotetext{
* The author is grateful to Alejandro Werner, Alejandro Santos, Luca Ricci, Adrián Armas, Paul Castillo, and participants in the presentation at the BCRP for their valuable comments and suggestions. All potential errors are mine.
} 


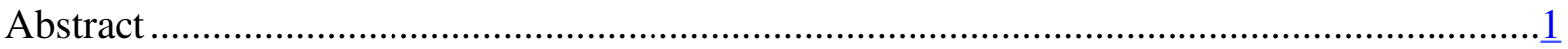

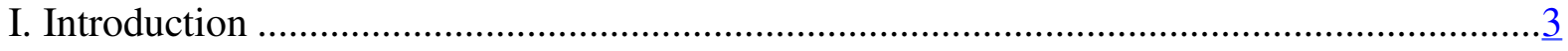

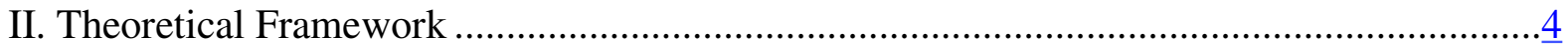

III. Empirical Model and Data Description ................................................................

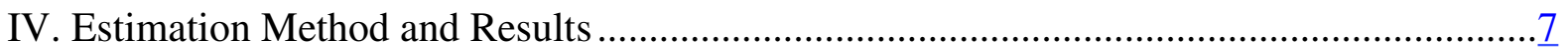

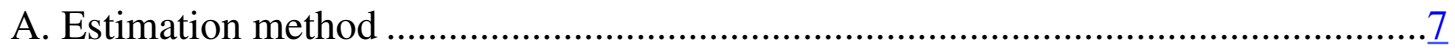

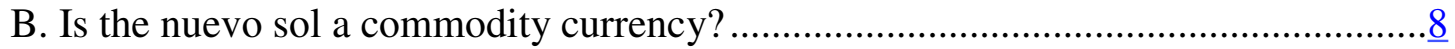

C. Identifying the drivers of the equilibrium real exchange rate ...........................13

D. Is the real effective exchange rate misaligned? .............................................

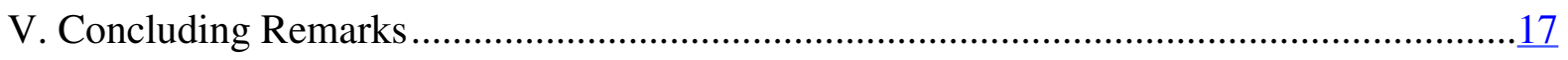

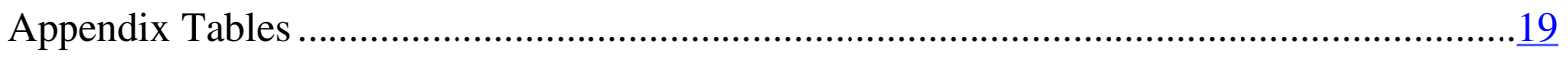

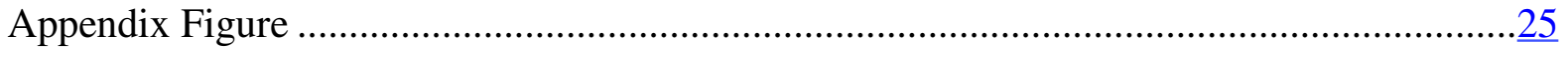

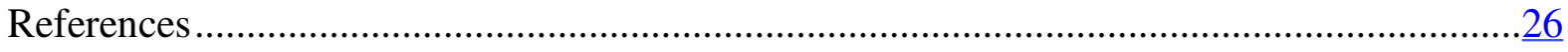




\section{INTRODUCTION}

Since the real exchange rate $^{1}$ is the relative price of tradable and non-tradable goods in an economy, understanding whether it is in line with the equilibrium level is important for efficient allocation of resources between the tradable and non-tradable sectors. A misaligned real exchange rate, i.e. a real exchange rate that deviates substantially from the equilibrium level, could create large macroeconomic imbalances and distort incentives and allocation of resources by sending wrong signals to economic agents.

While the equilibrium real exchange rate is an unobservable variable, economic theory suggests that it is driven by such observable economic fundamentals as the terms of trade (or the real prices of key export commodities for commodity dependent economies), relative productivity of tradables to non-tradables, government consumption, and the net foreign asset position. For commodity dependent economies like Peru, in particular, the equilibrium real exchange rate is conjectured to be primarily determined by the real prices of export commodities so much that their currencies are commonly referred to as 'commodity currencies' (Chen and Rogoff, 2003; Cashin et al, 2004; Bodart et al, 2012).

The essential step in estimating the equilibrium real exchange rate is establishing an econometric relationship between the real exchange rate and the fundamentals, which is the main objective of this study. In particular, the study aims to test if Peru's real exchange rate is primarily determined by the real prices of key export commodities as the 'commodity currency' hypothesis would suggest. To achieve this objective, the study employs the Johansen cointegration method. Robustness of the results is tested with various specifications, including with alternative definitions of the real exchange rate and real commodity prices, varying sample sizes, and alternative methodologies.

The paper also attempts to estimate the path of the notional equilibrium real exchange rate using the estimated long-run cointegration relationship between the real exchange rate and the fundaments. The equilibrium real exchange rate estimated in this study, however, does not have a normative implication as it does not necessarily imply optimality from a welfare perspective. A normative assessment of the equilibrium real exchange rate requires making judgments on the optimality of the values of the fundamentals, which is beyond the scope of this study.

The study is organized as follows. The theoretical framework is presented in Section II, followed by the empirical model and data description in Section III. Section IV presents the estimation results and Section $\mathrm{V}$ concludes the study.

\footnotetext{
${ }^{1}$ The terminologies 'real exchange rate' and 'real effective exchange rate' both of which refer to the exchange rate of the nuevo sol against a basket of currencies of major trading partner countries adjusted for price differentials between Peru and trading partner countries are used interchangeable in this study.
} 


\section{THEORETICAL FRAMEWORK}

Attempts to model the equilibrium real exchange rate goes back to the Purchasing Power Parity (PPP) theory, which states in its absolute form that the exchange rate between currencies of two countries is simply given by the relative price levels expressed in the same currency (i.e., generalization of the law of one price); and in its relative form, the theory asserts that the percentage change in the exchange rate between two currencies is determined by the inflation differential between the corresponding countries. In its weakest form, the PPP hypothesis requires deviations from the PPP real exchange rate to die out eventually and the real exchange rate to be stable, exhibiting a stationery or mean reverting property in the long run (Rogoff, 1996; Astorga, 2012). If this was true, the equilibrium real exchange rate would be constant and could be represented by the long-run or PPP real exchange rate. However, the PPP hypothesis received very little empirical support, especially in the short run, as most studies show that real exchange rate deviations are persistent and the real exchange rate exhibits a unit root process (Meese and Rogoff, 1983; Rogoff, 1996; Engel, 2000; Astorga, 2012).

The empirical failure of the PPP theory, referred in the literature as the PPP puzzle, has led to the hypothesis that the equilibrium real exchange rate could be time varying driven by real factors or fundamentals. In a seminal paper on the PPP puzzle, Rogoff (1996) argues that the high short-term volatility of the real exchange rate and the very slow adjustment of shocks to PPP are so irreconcilable that the deviations from PPP must be accounted for by real factors. Such real factors that are hypothesized to drive the equilibrium real exchange rate include the terms of trade (or real prices of commodities for commodity dependent economies), the relative productivity of tradables to non-tradables, government consumption, and net foreign asset position (Froot and Rogoff, 1995; Rogoff, 1996; Montiel, 2007; Ricci et al, 2013).

(i) Real price of commodities: While the terms of trade is generally used in real exchange rate models, for commodity dependent small open economies the real price index of key export commodities is a more relevant variable. As Chen and Rogoff (2003) indicate aggregate export and import price indices used to construct the terms of trade include goods with sluggish nominal price adjustments and incomplete pass-through, leading to identification problems in econometric estimations. On the contrary, world commodity prices are purely exogenous for small exporting economies as they are determined at the world markets. An increase in commodity prices can lead to wage increases in the commodity sector, and across the economy since labor is assumed to be mobile, leading to an increase in the relative price of non-tradables as the price of tradables is determine in the world market and, therefore, to a real exchange rate appreciation (Chen and Rogoff, 2003; Cashin et al, 2004).

(ii) Relative productivity of tradables to non-tradables: According to the Balassa-Samuelson hypothesis (Balassa, 1964; Samuelson, 1964), an increase in the relative productivity of tradables to non-tradables will drive up economy-wide wages, 
(iii) assuming labor is mobile between the two sectors, resulting in a higher relative price of non-tradables (i.e., a real appreciation).

(iv) Net foreign asset position: an increase in net foreign liabilities will require a more depreciated real exchange rate to generate the trade surplus necessary to service the external debt (Rogoff, 1996; Ricci et al, 2013).

(v) Government consumption: higher government consumption is likely to lead to an appreciation of the equilibrium real exchange rate since government consumption tends to fall more on nontradables than tradables (Froot and Rogoff, 1995; Rogoff, 1996; Ricci et al, 2013).

\section{EMPIRICAL MODEL AND DATA DESCRIPTION}

To test if the nuevo sol is a commodity currency, this study follows Chen and Rogoff (2003) and Cashin et al (2004), who specify the real effective exchange rate as a function only of the real price of commodities. Given Peru's reliance on commodity exports, in particular metals ${ }^{2}$ such as copper and gold, the hypothesis of commodity currency expects Peru's real effective exchange to be driven primarily by the real price of export commodities. Hence, the regression model takes the following log-linear form:

$$
\operatorname{LREER}_{t}=\alpha_{0}+\alpha_{1} \text { LRP_COM }_{t}+\mu_{t}
$$

Where,

$R E E R=$ the real effective exchange rate index, which is a trade-weighted and exchange-rate-adjusted ratio of domestic to foreign prices; an increase in the REER is an appreciation. For the robustness exercise, the bilateral real exchange rate index (RER) vis-à-vis the US dollar is also used. The source of REER data is IMF's Information Notice System (INS) database and the RER is constructed using data on the bilateral exchange rate and prices from the IMF's International Financial Statistics (IFS) database.

$R P \_C O M=$ the real price of export commodities, constructed as the weighted average world price indices of copper, gold, lead and zinc (Peru's major export metals) deflated by the manufacturing export unit value index (MUVI) of advanced economies. Metal price indices are obtained from the IFS database and the MUVI is from the IMF's World Economic Outlook (WEO) database.

$\mu=$ stochastic error term.

$L=$ Natural logarithm transformation operator

$t=$ time index.

\footnotetext{
${ }^{2}$ Metal exports represent about 55 percent of Peru's total export receipts..
} 
The nuevo sol would be regarded as a commodity currency if $\alpha_{1}$ is positive and statistically significant.

To identify the drivers of the equilibrium real effective exchange rate more generally, equation (1) is modified by including the remaining fundamentals and is re-specified as:

$$
\operatorname{LREER}_{t}=\beta_{0}+\beta_{1} * L R P_{-} C O M_{t}+\beta_{2} * L P R O D_{t}+\beta_{3} * L G C N_{t}+\beta_{4} * L N F L_{t}+\varepsilon_{t}
$$

Where,

- $\quad$ PROD $=$ the relative productivity. The economy-wide labor productivity of Peru relative to a trade-weighted average labor productivity of trading partner countries is used since data on sectoral productivity is not available. The implicit assumption is that productivity growth is likely to be biased in favor of the tradable sector, meaning that a country with high growth of overall productivity will also exhibit higher productivity growth in the tradable sector relative to that of the non-tradable sector. Source of data is Haver.

- $\quad \mathrm{GCN}=$ the primary current public sector consumption (spending on wages and salaries and goods and services) as a ratio of GDP of Peru relative to that of trading partner countries. Only U.S. data is used in the denominator as consistent time series data is not available for most other trading partner countries such as China, Brazil and Chile. Sources of data are the Central Reserve Bank of Peru (BCRP) and the U.S. Bureau of Economic Analysis (BEA).

- $\mathrm{NFL}=$ the stock of net foreign liability at end of previous period as a ratio of previous period's total external trade in goods and services. As alternatives, NFL as a ratio of GDP and the cumulative current account balance (as a ratio trade and GDP) are explored. Source of data is the BCRP.

- $\varepsilon=$ stochastic error term.

- All other terms are as defined above

The sample covers quarterly data for the period 1992-2013. The year 1992 was chosen as the beginning of the sample period to avoid potential structural shifts in the real exchange rate data due to changes in currency prior to 1992 and major stabilization efforts realized since then. Peru's current currency, the nuevo sol, was introduced and has been in use since July 1991. For robustness exercise, however, annual data for the sample period 1970-2013 and monthly data for the sample period 1992-2013 were also used.

Descriptive analysis of the data shows that Peru's real effective exchange rate is strongly correlated with the relative productivity and the relative government consumption. On the other hand, the real effective exchange rate does not seem to have a discernible correlation 
with the real commodity price index and its correlation with the net foreign liability appears to shift from positive prior to 2007 to negative since 2007 (Appendix Figure).

\section{Estimation Method AND ResUlts}

\section{A. Estimation method}

Graphical inspection of data shows that the real effective exchange rate does not seem to exhibit a stationary process as there is a visual evidence of drift in the data (Figure 1a). The first difference of the real exchange rate, however, clearly portrays a stationary process (Figure 1b). This observation is supported by the results of formal unit root tests, which show that Peru's real effective exchange rate follows an I(1) process (Appendix Table 1). Unit root tests for the fundamentals also shows that they are all integrated of order one (Appendix Table 1), implying that the right approach for estimating the real effective exchange rate equation is a cointegration analysis. Hence, the Johansen cointegration method is used to test and estimate cointegration relationships between the REER and the fundamentals. Alternative estimation methods, including the Dynamic OLS (DOLS), the Fully Modified OLS (FMOLS), and the Two-Stage Least Squares (2SLS) methods, are also explored to test the robustness of the results to changes in estimation methodology.

Figure 1. Peru: Real Effective Exchange Rate (in logarithm)

(a) Level

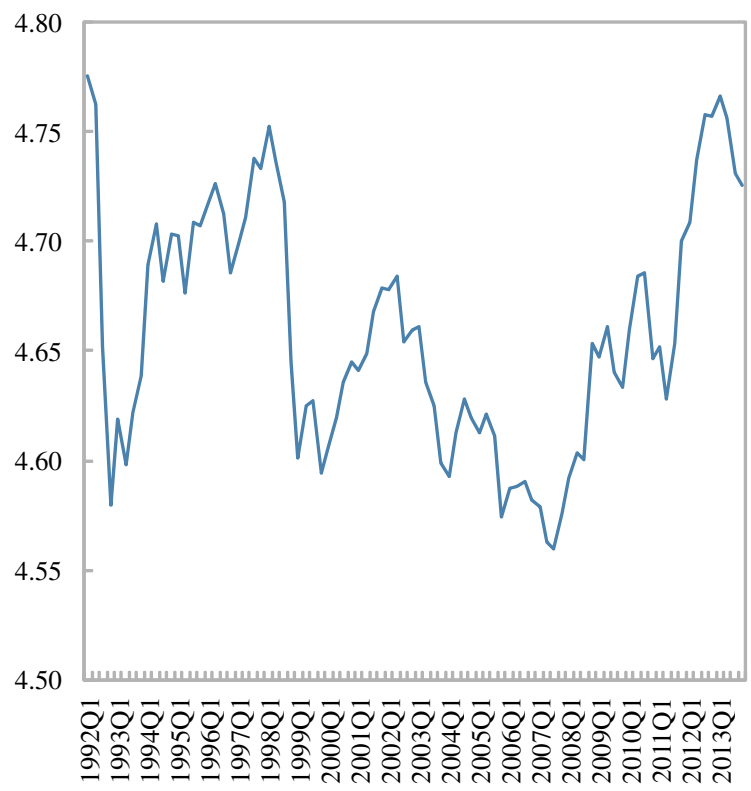

(b) First Difference

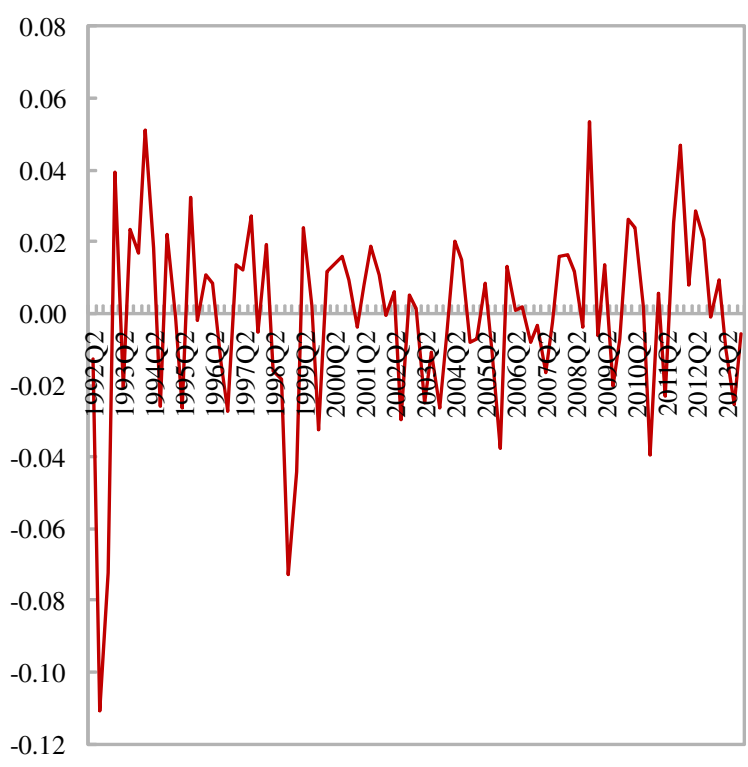

Source: IMF and Author's calculations. 


\section{B. Is the nuevo sol a commodity currency?}

\section{i) The results}

The estimated results below suggest that the real price index of commodities does not explain the behavior of the REER (the number in parenthesis is the t-value).

$$
\text { LREER }_{t}=4.55+0.02 * L_{R} P_{-} C O M_{\mathrm{t}}
$$

Although Johansen's Trace and Maximum Eigenvalue tests indicate the presence of cointegration at 10 percent level (Appendix Table 2a), the estimated coefficient on LRP_COM is very small and not statistically significant, ruling out the null hypothesis of a commodity currency. The result is robust to changes in the definition of the real exchange rate (using the RER instead of the REER) and the RP_COM (using the real price of copper and the terms of trade in place of RP_COM), data frequency (using monthly and annual data), estimation method, and sample coverage (Table 1). In all cases, the coefficients are positive as expected, but not statistically significant.

Table 1. Peru: The Real Exchange Rate and Commodity Price: Alternative Specifications

\begin{tabular}{|l|c|c|}
\hline Alternative specification & Coefficient & T-value \\
\hline Dynamic OLS & 0.03 & 1.21 \\
\hline Fully Modified OLS & 0.02 & 0.43 \\
\hline RER as dependent variable & 0.05 & 0.87 \\
\hline Real price of copper & 0.02 & 0.73 \\
\hline Terms of trade & 0.04 & 0.41 \\
\hline Monthly data: 1992-2013 & 0.03 & 1.17 \\
\hline Annual data: 1970-2013 & 0.01 & 0.11 \\
\hline
\end{tabular}

The test for linear cointegration in the annual sample yielded no cointegration with coefficients sensitive to changes in specification. Since this might be due to potential structural breaks (regime shifts) as the Peruvian economy underwent through significant turbulences (including hyperinflation and changes in currency) in the 1980s, Gregory-Hansen cointegration test with a regime shift was used to test for evidence of a non-linear cointegration between the REER and RP_COM. The result shows evidence of non-linear cointegration with a regime shift in 1987 at 10 percent level (Appendix Table 3a). Following this result, a dummy was created for this structural shift and the non-linear cointegration relationship was estimated using FMOLS with LRP_COM and LRP_COM interacted with a dummy for a structural shift on the right hand side. The estimated coefficients were -0.26 for 
LRP_COM and 0.27 for LRP_COM interacted with a dummy with a net elasticity of 0.01 after the structural shift, i.e. for the period 1987-2013, which is comparable to the sample period of the monthly and quarterly frequency data. Both coefficients were statistically significant, but Wald restriction test for the sum of the coefficients equals zero could not be rejected at any level of significance (Appendix Table 4c).

ii) Possible explanations for why the nuevo sol may not be a commodity currency

While most similar studies on other commodity dependent economies find evidence of commodity currency, Peru was one of the few countries with no such evidence in Cashin et al (2004) as well (Appendix Table 5). The absence of a statistically significant long run relationship between export commodity prices and the real effective exchange rate in an economy that relies heavily for exports on commodities, and that faced significant positive commodity price shocks in the study period, is somewhat puzzling. Potential factors that could have weakened the statistical relationship between the commodity prices and the real effective exchange rate may include large profit repatriation and active foreign exchange intervention.

(i) Profit repatriation: Despite significant price increases for its exports, Peru has run current account deficits during most of the past decade as large profit repatriations more than offset trade surpluses (Figure 2). The mining sector in Peru is operated by the private sector, mostly owned by non-residents. As a result, most of the profit from the sector is repatriated. During 2003-13, the time identified by Adler and Magud (2013) as the commodity income windfall period, profit repatriation from Peru amounted to about 6 percent of GDP a year on average. This might have weakened the statistical relationship between the commodity prices and the real effective exchange rate since a large part of the commodity price shock might have been leaked as profit repatriation without having a significant impact on domestic demand. It is true that a large part of the repatriated profit has been reinvested in Peru in the mining sector, but the investments are mostly on imported machineries with limited impact on domestic demand. 
Figure 2. Peru: Real Price of Commodities, Profit Repatriation, and Current Account Balance

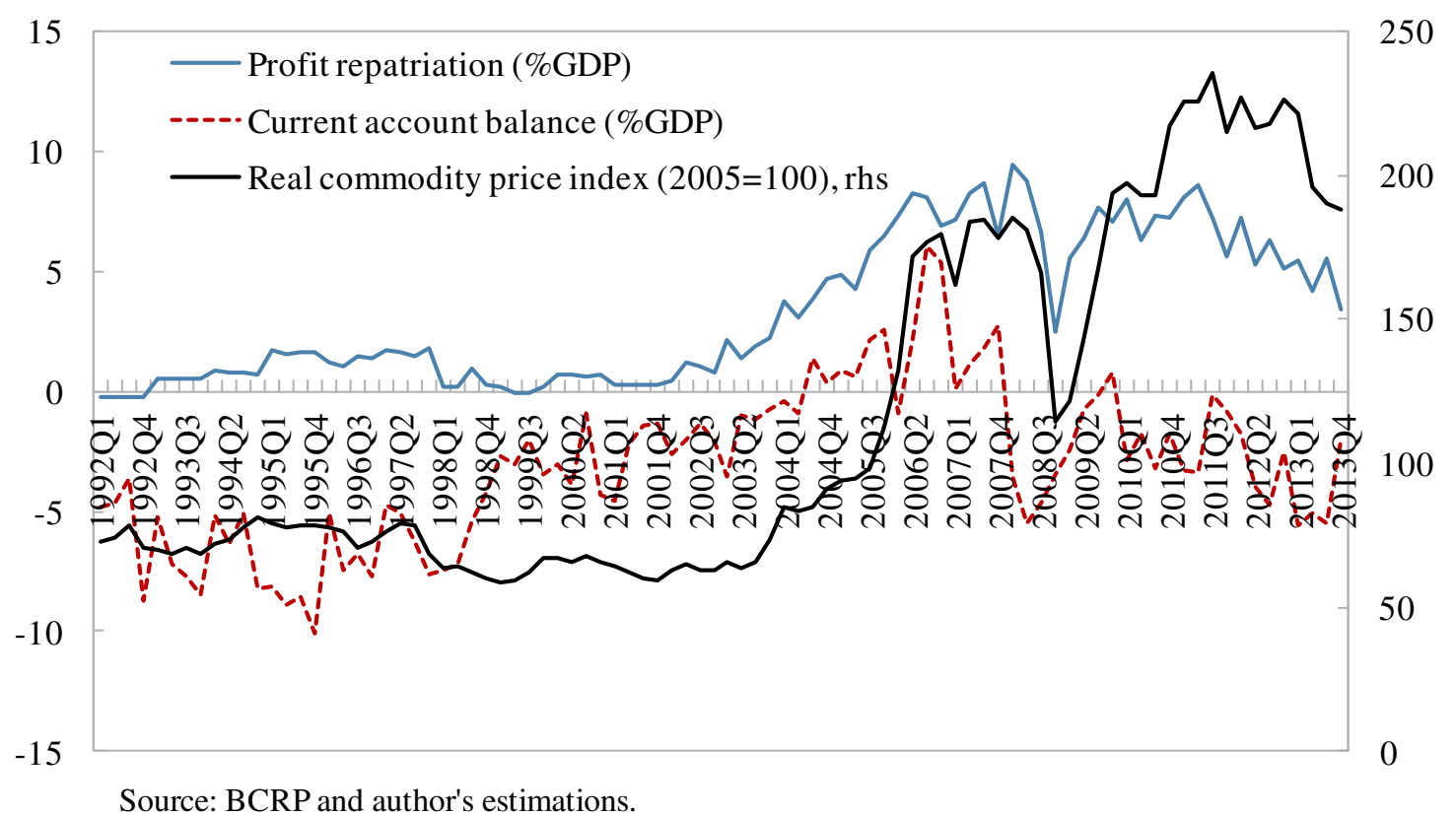

(ii) Active FX intervention: Peru's central bank intervenes actively in the forex market with a stated objective of limiting exchange rate volatility to contain the risks of financial dollarization. Empirical evidence shows that the BCRP's forex interventions are successful in containing exchange rate volatility (Tashu, 2014). On the other hand, Peru has one of the lowest and most stable rates of inflation in the region, thanks to an inflation targeting framework which has successfully anchored inflation expectations (Armas and Grippa, 2005; Armas et al 2014) ${ }^{3}$. As a result, Peru's real exchange rate is the most stable among financially open large Latin American economies (Figure 3).

\footnotetext{
${ }^{3}$ While the inflation targeting framework was introduced in 2002, the monetary targeting framework, which was in place prior to 2002, is also credited to have reduced and stabilized inflation from the 1980s hyperinflation.
} 
Figure 3. Real Effective Exchange Rate Indices in Selected Latin American Economies ${ }^{1}$ $(2010=100)$

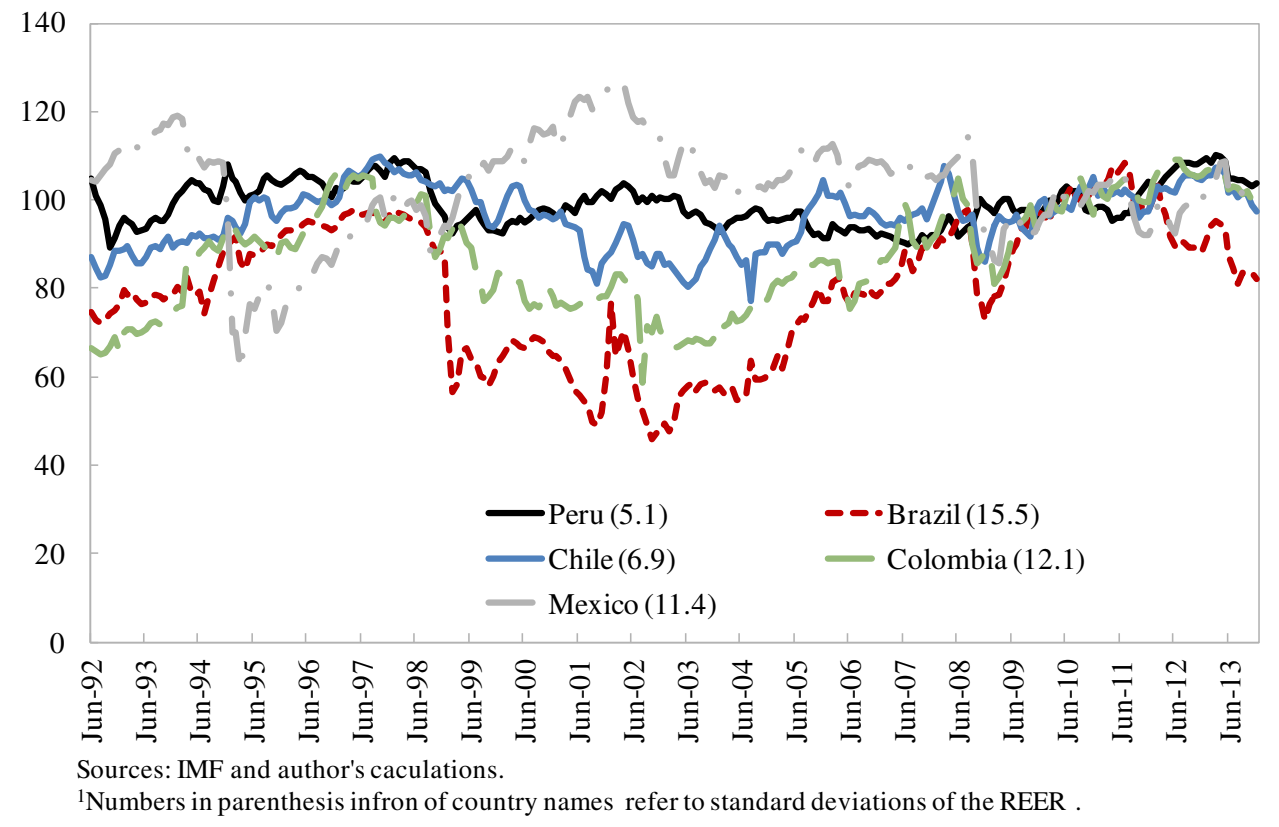

A sustained sterilized forex intervention ${ }^{4}$ in an inflation targeting regime appears to have weakened the impact of commodity prices on the real exchange rate. To illustrate this, consider a positive commodity price shock. In an inflation targeting regime, the central bank could prevent the inflationary pressure from the commodity windfall income by increasing its policy rate, which in turn can lead to an increase in capital inflows. In a freely floating exchange rate regime, the capital inflows would have appreciated the nominal, and hence the real, exchange rate. The BCRP's sterilized forex intervention has, however, limited the impacts of capital inflows on the exchange rate, effectively insulating the real exchange rate from the impact of commodity price shocks.

To test the hypothesis that large profit repatriations and the central bank's forex interventions could have insulated the REER from the impact of commodity prices, consider a specification where the REER depends on the commodity prices, profit repatriation in

\footnotetext{
${ }^{4}$ Complementary fiscal policy and the use of reserve requirements have helped the BCRP sustain its sterilized forex interventions without compromising the health of its balance sheet. For instances, about $371 / 2$ percent and $341 / 2$ percent of the forex intervention in 2013 was sterilized by public sector deposits and reserve requirements, respectively, and only about $11^{1 / 2}$ percent of the intervention was sterilized through central bank instruments (Rossini et al, 2014). In this regard, the positive commodity price shock, which increased tax revenues from the mineral sector, has helped the Treasury to provide support to the central bank's sterilization effort.
} 
percent of GDP (PREP), and net international reserves in percent of GDP (NIR) as a proxy for forex intervention ${ }^{5}$.

$$
\operatorname{LREER}_{t}=\theta_{0}+\theta_{1} * \operatorname{LRP}_{-} \mathrm{COM}_{t}+\theta_{2} * \operatorname{LPREP}_{t}+\theta_{3} * L N I R_{t}+\epsilon_{t}
$$

Profit repatriation should lead to a depreciation of the nominal, and hence the real, exchange rate because it increases demand for foreign exchange. As a result, $\theta_{2}<0$. The NIR is also expected to have a negative relationship with the real exchange rate as an increase in the NIR (forex purchases by the central bank) and a decrease in NIR (forex sales by the central bank) should lead to a depreciation and appreciation of the national currency, respectively, if successful. Hence, $\theta_{3}<0$.

Since changes in the commodity prices can also affect profit repatriation and net international reserves, we can specify the following equations:

$$
\begin{aligned}
& \operatorname{LPREP}_{t}=\gamma_{0}+\gamma_{1} * L R P_{-} C O M_{t}+\varphi_{t} \\
& \operatorname{LNIR}_{t}=\delta_{0}+\delta_{1} * L R P \text { COM }_{t}+\tau_{t}
\end{aligned}
$$

From (4), the impact of commodity prices on the REER if we were to hold PREP and NIR constant is $\theta_{1}$. In reality, however, both PREP and NIR change when commodity prices change. Firms' profit increases as commodity prices increase, implying $\gamma_{1}>0$, and a positive commodity price shock prompts central bank intervention in the forex market and hence an increae in the NIR, implying $\delta_{1}>0$. As a result, the net impact of commodity prices on the REER is given by $\left(\theta_{1}+\theta_{2} * \gamma_{1}+\theta_{3} * \delta_{1}\right)$, and could be zero, negative or positive depending on the relative size of the individual coefficients.

Estimation of equations (4)-(6) using the Johansen cointegration method ${ }^{6}$ yields the following results:

\footnotetext{
${ }^{5}$ The NIR used here excludes valuation effects so that changes in NIR reflect mostly of forex interventions and other measures aimed at containing exchange rate volatility such as changes in reserve requirements on foreign currency liabilities.

${ }^{6}$ All of the variables have unit root (Appendix Table 1). The Augmented-Dickey-Fuller (ADF) test seems to suggest that LNIR is I(0) when constant or constant and trend are added. But the ADF test is known to have low power; i.e., has the tendency to reject the null hypothesis of I(1) too often when it is true. The more efficient unit root test, the Dickey-Fuller GLS (DF-GLS) test, however, accepts the null hypothesis at all levels of significance, suggesting that the NIR is I(1). Johansen's Trace and Maximum Eigenvalue cointegration tests show the presence of a statistically significant cointegration vector among the variables in each of the three equations.
} 


$$
\begin{aligned}
& \text { LREER }_{t}=4.22+0.49 * \text { LRP_COM }_{t}-0.16 * \operatorname{LPREP}_{t}-0.56 * \mathrm{LNIR}_{t} \\
& P R E P_{t}=-3.87+1.01 * L R P_{-} C O M_{t} \\
& L N I R_{t}=0.38+0.55 * L R P_{-} C_{C O M}
\end{aligned}
$$

The results show that all of the coefficients have the expected sign and are statistically significant at standard levels of significance. Furthermore, the estimate for the net impact of the commodity prices $\left(\theta_{1}+\theta_{2} * \gamma_{1}+\theta_{3} * \delta_{1}\right)$, equals 0.01 , which is very low and virtually the same as the estimated coefficient obtained when the real effective exchange rate is regressed only on the commodity prices (equation (3)).

Thus, the empirical evidence supports the hypothesis that the commodity price shock has been absorbed mostly by large profit repatriations and a sustained forex intervention, weakening the net impact on the real effective exchange rate. The impact of commodity prices on the real effective exchange rate, if we were to hold profit repatriation constant and assume no forex intervention, would have been statistically significant with an estimated elasticity of about 0.5 . In reality, however, changes in commodity prices have statistically significant positive impact on profit repatriation and central bank intervention, which in turn affect the real effective exchange rate negatively, neutralizing the initial impact of the commodity prices on the real effective exchange rate.

\section{Identifying the drivers of the equilibrium real exchange rate}

The search for a cointegrating vector between the REER and fundamentals involved an algorithm, which: (i) discards models that do not have a statistically significant vector; (ii) eliminates variables which do not have coefficients with theoretically expected sign or whose inclusion changes the signs of other variables; (iii) discards models which do not have a statistically significant error correction term with negative sign; and (iv) maximizes the $\mathrm{R}$ square of the ECM. The net foreign liability was dropped from the chosen model, following this algorithm, similar to the results of other studies, including Montiel (2007) and Coudart et al (2011). Test for cointegration among the remaining variables shows a single cointegrating vector at 10 percent significant level (Appendix Table 2b), which after normalizing for the coefficient of LREER, takes the following form:

$$
L_{R E E R_{t}}=4.74+0.03 * L R P{ }_{-} C O M_{t}+0.36 * L P R O D_{t}+0.37 * L G C N_{t}
$$

Where numbers in parenthesis refer to t-values. 
While all of the fundamentals in equation (10) have the expected signs on their coefficients, the real price of commodities is not statistically significant as is the case in equation (3). Tests for cointegration restrictions show that LRP_COM is not important for the cointegrating vector (Appendix Table 2c). As a result, equation (10) is re-estimated without LRP_COM and the resulting cointegration vector, which becomes statistically significant at 1 percent level (Appendix Table 2d), and the short-run dynamic equation are shown in equations (11) and (12), respectively:

$$
\begin{gathered}
\text { LREER }_{t}=4.90+0.48 * L P R O D_{t}+0.39 * L G C N_{t} \\
(3.57) \\
D_{L R E E R_{t}=} 0.0001-0.13 * E C M_{t-1}+0.22 * D L R E E R_{t-1} \\
(0.05)(-3.02) \\
+0.45 * D L P R O D_{t-1}-0.09 * D L G C N_{t-1}
\end{gathered}
$$

Where, D-stands for the first difference, the subscript (-1) refers to the first lag, and ECM stands for the error correction term, which is the error term of equation (11). Numbers in parenthesis are t-values.

Accordingly, relative productivity and government consumption are the main drivers of the equilibrium real effective exchange rate in Peru. The coefficient on the error correction term in the dynamic equation is -0.13 and is statistically significant at 1 percent implying that about 13 percent of deviations of the real exchange rate from the long run equilibrium would be corrected after one quarter. The half-life of a shock to the REER, calculated as $\log (0.5) / \log (1-0.13)$, is estimated at about 5 quarters, which is consistent with the results of other empirical studies. Both productivity and government consumption are also significant in the short run dynamic model (equation (12)), the latter with an unexpected negative sign.

The above result is robust to changes in specifications (Table 2). The exception is when annual data for 1970-2013 is used, which show a statistically significant RP_COM, but the elasticity remains very small $(0.03)^{7}$.

\footnotetext{
${ }^{7}$ The results for the annual data are obtained following the procedure described above; i.e. testing for cointegration with regime shift using Gregory-Hansen's test and estimating the long-run relationship using nonlinear FMOLS (Appendix Tables 3b, 4b and 4c). In this case, the break was identified as 1988/89.
} 
Table 2. Peru: The Real Exchange Rate and Fundamentals: Alternative Specifications ${ }^{1 /}$

\begin{tabular}{|l|l|l|l|}
\hline Alternative Specification & LRP_COM & LPROD & \multicolumn{1}{l}{ LGCN } \\
\hline $\begin{array}{l}\text { Two-stage Least Squares } \\
\text { (using first lags as instruments) }\end{array}$ & $\begin{array}{l}0.01 \\
(0.52)\end{array}$ & $\begin{array}{l}0.43 \\
(8.59)\end{array}$ & $\begin{array}{l}0.14 \\
(2.09)\end{array}$ \\
\hline Dynamic OLS & $\begin{array}{l}0.02 \\
(0.95)\end{array}$ & $\begin{array}{l}0.36 \\
(3.63)\end{array}$ & $\begin{array}{l}0.15 \\
(1.95)\end{array}$ \\
\hline Fully Modified OLS & 0.01 & 0.36 & 0.11 \\
& $(0.83)$ & $(4.20)$ & $(1.71)$ \\
\hline RER as dependent variable ${ }^{2 /}$ & $\ldots$ & 0.92 & 0.41 \\
\hline Real price of copper & $\cdots$ & $(3.32)$ & $(2.87)$ \\
\hline Terms of trade & 0.02 & 0.40 & 0.41 \\
& $(1.05)$ & $(3.08)$ & $(4.38)$ \\
\hline Annual data: $1970-2013^{3 /}$ & 0.05 & 0.43 & 0.41 \\
& $(0.65)$ & $(3.12)$ & $(4.22)$ \\
\hline
\end{tabular}

\footnotetext{
${ }^{1 /}$ Numbers in parenthesis are t-values.

${ }^{2 /}$ RP_COM is dropped from the bilateral RER model as it carries theoretically-wrong sign.

${ }^{3 /}$ Net foreign liability also becomes significant with theoretically-expected negative sign and elasticity of 0.06. Trade openness index, which was not included in the quarterly data since Peru liberalized its external trade in 1991, is also included in the annual sample (Appendix Tables $4 \mathrm{~b}$ and $4 \mathrm{c}$ ).
}

\section{Is the real effective exchange rate misaligned?}

While a proper estimation of the equilibrium real exchange rate requires a multi-country panel regression analysis similar to the IMF's external balance assessment (Phillips et al, 2013), the estimated long-run relationship between the REER and statistically significant fundamentals is used to estimate the notional path of the equilibrium REER. The idea is to evaluate how much the actual real effective exchange rate is aligned with the path of the real effective exchange rate predicted by estimated long-run cointegration relationship (equation (11)) and the values of statistically significant fundamentals. In theory, the equilibrium real effective exchange rate is the value of the real effective exchange rate predicted by the 'sustainable' or 'steady state' values of the fundamentals (Montiel, 2007). Hence, the fundamentals are filtered by the Hodrick-Prescott (HP) filter to remove cyclical components and estimate their sustainable components.

The actual, fitted, and equilibrium REER are presented in Figure 4a along with the estimated misalignment in Figure 4b. The fitted value tracks the actual REER very well, indicating a very good fit to data. As a result, the statistical error of the estimated equilibrium REER is likely to be negligible. 
Figure 4. Peru: The Equilibrium Real Effective Exchange Rate
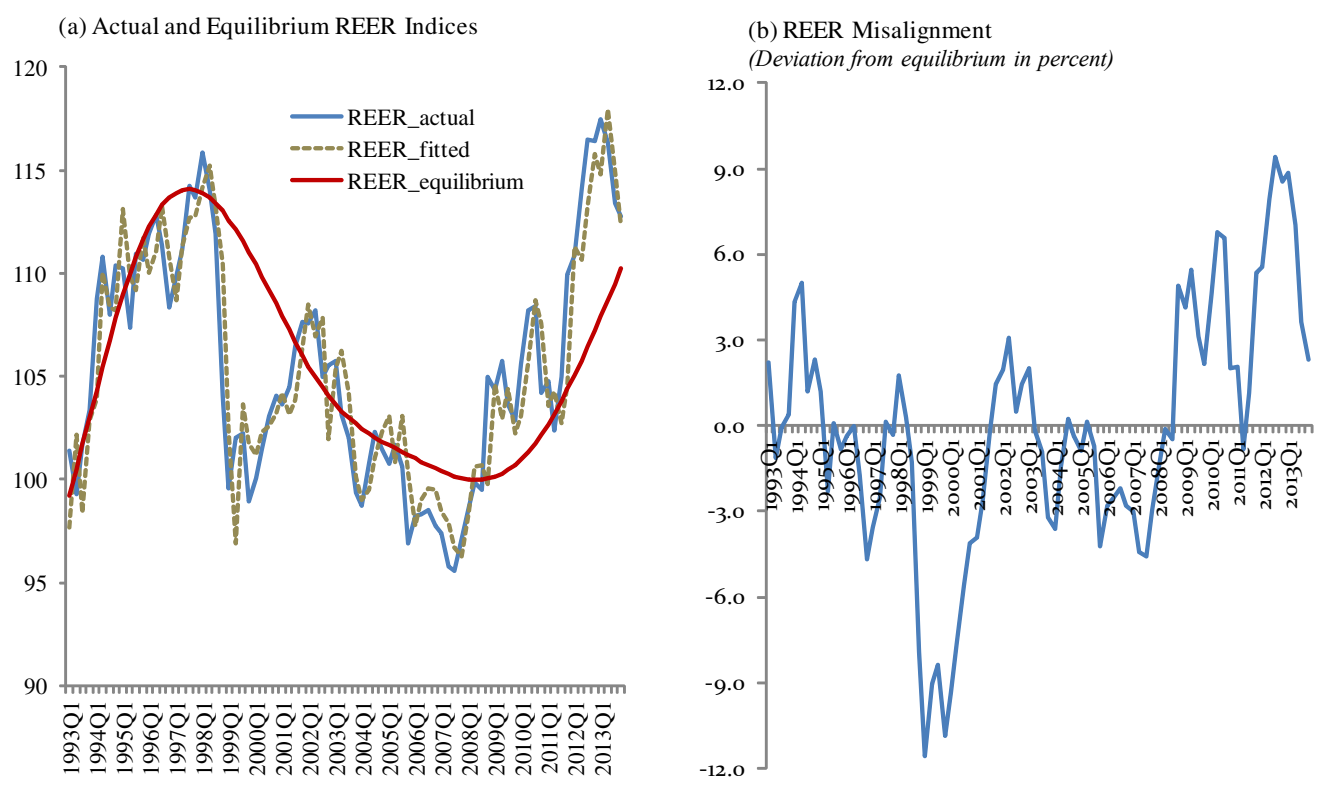

Sources: IMF and author's calculations.

The estimated results show that, over the past decade, Peru's real effective exchange rate appears to have been broadly in line with the fundamentals with the exception of mild misalignments in some years. In particular, the REER was:

- Mildly undervalued during 2004-07 by 21/4 percent on average: the REER depreciated about 4 percent during this period, while the equilibrium REER depreciated about 2 percent as the impact of large retrenchments in government consumption (relative to the U.S.) more than offset the impact of improvements in relative productivity (Table 3 and Figure 5).

- Consistent with the equilibrium REER in 2008.

- Mildly overvalued during 2009-13 by about 43/4 percent on average: possibly because the massive capital inflow, which caused a significant REER appreciation (14 percent), was driven not only by Peru's fundamentals, which justified only 9 percent equilibrium REER appreciation, but also by global push factors. However, a large part of the misalignment, which peaked in the $1^{\text {st }}$ quarter of 2013 at $83 / 4$ percent, was corrected in the second half of 2013, as the nuevo sol depreciated following the U.S. Fed Reserve's announcement of monetary policy tapering. (Table 3 and Figure 5)

It is important to note that this assessment does not necessarily have a normative value as a REER close to its equilibrium level may still reflect distortions in the fundamentals (Phillips et al, 2013). A normative assessment of the equilibrium REER requires making judgments on 
the 'appropriateness' of the fundamentals from a welfare perspective, which is beyond the scope of this study.

Table 3. Peru: Actual and Estimated Equilibrium Real Effective Exchange Rate

\begin{tabular}{cccc}
\hline Year & Actual & Equilibrium & Misalignment \\
\hline 2004 & 100.8 & 102.1 & -1.3 \\
2005 & 100.0 & 101.4 & -1.4 \\
2006 & 98.2 & 100.8 & -2.6 \\
2007 & 96.5 & 100.2 & -3.7 \\
2008 & 100.8 & 100.0 & 0.7 \\
2009 & 104.1 & 100.4 & 3.7 \\
2010 & 106.6 & 101.6 & 5.0 \\
2011 & 105.5 & 103.5 & 1.9 \\
2012 & 114.5 & 106.1 & 7.9 \\
2013 & 115.0 & 109.1 & 5.4 \\
\hline
\end{tabular}

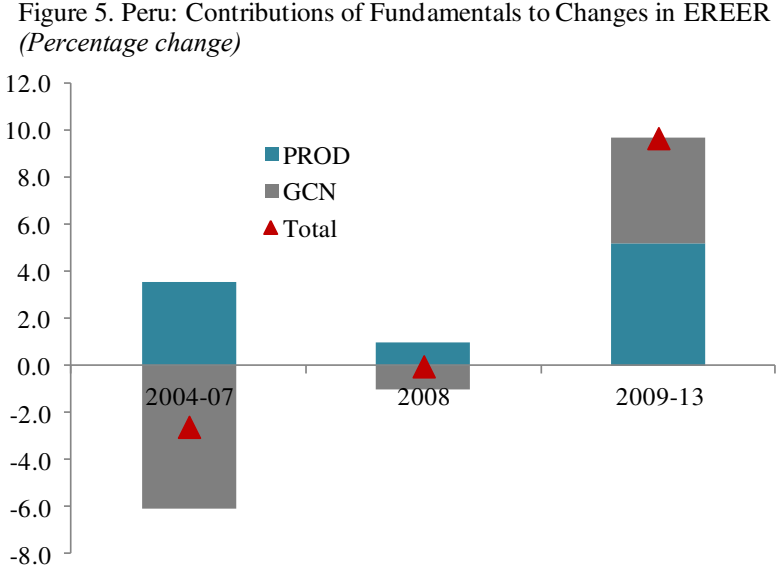

\section{Concluding Remarks}

This study conducts a cointegration analysis to test the hypothesis of the commodity currency and identify the drivers of Peru's equilibrium real exchange rate. The first part of the empirical analysis involves testing the hypothesis of 'commodity currency' on the nuevo sol. The results show that the real price index of Peru's export commodities does not have a statistically significant impact on the real effective exchange rate, suggesting that the nuevo sol is not a commodity currency. This appears puzzling for a country that relies heavily on metal commodities for its exports. The paper shows empirically that large profit repatriation and the BCRP's active forex intervention could have mitigated the impact of commodity prices on the real effective exchange rate.

The second part of the empirical analysis identifies the main drivers of the equilibrium real exchange rate from a pool of economic fundamentals that include the real price of commodities, Peru's productivity relative to that of trading partners, Peru's government consumption relative that of trading partners, and the net foreign liability. The results show that only productivity and government consumption, both relative to that of trading partners, have statistically significant relationships with the real effective exchange rate, suggesting that the equilibrium REER is driven only by these two fundamentals.

The equilibrium real effective exchange rate is estimated based on the cointegrating relationship between the real effective exchange rate and the statistically significant fundamentals. The results show that Peru's real effective exchange rate is broadly in line with the notional equilibrium level predicted by the 'sustainable' values of the fundamentals. The REER was mildly overvaluated in the years following the 2008 global financial crisis, which is not surprising given the surge in capital inflows triggered mostly by easy monetary policy in advanced economies. But the recent depreciation of the REER following the U.S. Fed Reserve announcement of unconventional monetary policy tapering in May 2013 appears to have mostly corrected the overvaluation. This does not necessarily imply that all is well with the level of the real exchange rate from a welfare perspective as the equilibrium 
real exchange rate itself could be the result of distortions in the fundamentals (suboptimal levels of government consumption, for instance). Making such a normative assessment requires determining the optimal or 'welfare maximizing' levels of the fundamentals, which is beyond the scope of this study.

The results of the study on the equilibrium real exchange rate need to be interpreted only as indicative since a proper exchange rate assessment requires a panel data based analysis, in line with the IMF's EBA assessment, to deal with technical problems associated with small sample size and potential structural breaks. 


\section{APPENDiX TABLES}

Table 1. Unit Root Test Results ${ }^{1 / 2 /}$

\begin{tabular}{|c|c|c|c|c|c|c|c|}
\hline \multirow{2}{*}{ Variable } & & \multicolumn{3}{|c|}{ ADF t-statistic } & \multicolumn{2}{|c|}{ DF-GLS t-statistic } & \multirow[b]{2}{*}{ Remarks } \\
\hline & & None & Constant & $\begin{array}{c}\text { Contant } \\
\text { and trend }\end{array}$ & Constant & $\begin{array}{l}\text { Contant } \\
\text { and trend }\end{array}$ & \\
\hline \multirow{2}{*}{$\begin{array}{l}\text { Real effective } \\
\text { exchange rate }\end{array}$} & Level & -0.24 & -2.59 & -2.44 & -1.36 & -1.71 & \multirow{2}{*}{$I(1)$} \\
\hline & Difference $\left(1^{\mathrm{st}}\right)$ & -7.51 & -7.46 & -7.53 & -7.01 & -7.58 & \\
\hline \multirow{2}{*}{$\begin{array}{l}\text { Real bilateral } \\
\text { exchange rate }\end{array}$} & Level & -0.20 & -2.37 & -1.70 & -1.24 & -1.37 & \multirow{2}{*}{$I(1)$} \\
\hline & Difference $\left(1^{\text {st }}\right)$ & -6.93 & -6.89 & -6.96 & -6.73 & -7.01 & \\
\hline \multirow{2}{*}{$\begin{array}{l}\text { Real price index of } \\
\text { export commodities }\end{array}$} & Level & 0.84 & -0.73 & -2.13 & -0.41 & -1.76 & \multirow{2}{*}{$I(1)$} \\
\hline & Difference $\left(1^{\text {st }}\right)$ & -6.75 & -6.80 & -6.79 & -6.84 & -6.84 & \\
\hline \multirow{2}{*}{ Real price of copper } & Level & 0.57 & -0.89 & -2.54 & -0.65 & -1.87 & \multirow{2}{*}{$I(1)$} \\
\hline & Difference $\left(1^{\text {st }}\right)$ & -7.01 & -7.02 & -7.01 & -7.06 & -7.07 & \\
\hline \multirow{2}{*}{ Terms of trade } & Level & 0.06 & -1.78 & -2.41 & -1.78 & -2.19 & \multirow{2}{*}{$I(1)$} \\
\hline & Difference $\left(1^{\text {st }}\right)$ & -6.38 & -6.34 & -6.29 & -6.21 & -6.24 & \\
\hline \multirow{2}{*}{ Relative productivity } & Level & -0.57 & -0.93 & -0.54 & -0.91 & -0.73 & \multirow{2}{*}{$I(1)$} \\
\hline & Difference $\left(1^{\text {st }}\right)$ & -8.01 & -7.98 & -7.99 & -2.50 & -6.19 & \\
\hline \multirow{2}{*}{$\begin{array}{l}\text { Relative government } \\
\text { consumption }\end{array}$} & Level & -1.05 & -2.44 & -2.51 & -0.48 & -1.11 & \multirow{2}{*}{$I(1)$} \\
\hline & Difference $\left(1^{\text {st }}\right)$ & -15.08 & -15.03 & -17.08 & -1.67 & -3.46 & \\
\hline \multirow{2}{*}{ Net foreign liability ${ }^{3 /}$} & Level & -0.95 & -0.65 & -1.44 & 0.53 & -1.43 & \multirow{2}{*}{$I(1)$} \\
\hline & Difference $\left(1^{\text {st }}\right)$ & -6.97 & -7.36 & -7.32 & -7.38 & -7.33 & \\
\hline \multirow{2}{*}{$\begin{array}{l}\text { Net international } \\
\text { reserves }{ }^{4 /}\end{array}$} & Level & 2.50 & -4.46 & -4.35 & 0.94 & -1.03 & \multirow{2}{*}{$I(1)$} \\
\hline & Difference $\left(1^{\text {st }}\right)$ & -6.34 & -6.81 & -7.14 & -4.53 & -5.60 & \\
\hline \multirow{2}{*}{ Profit repatriation ${ }^{4 /}$} & Level & -0.58 & -1.50 & -2.38 & -0.90 & -2.51 & \multirow{2}{*}{$I(1)$} \\
\hline & Difference $\left(1^{\text {st }}\right)$ & -12.16 & -12.12 & -12.10 & -11.93 & -11.63 & \\
\hline \multicolumn{8}{|l|}{ Critical Values } \\
\hline \multicolumn{2}{|c|}{$1 \%$} & -2.59 & -3.51 & -4.07 & -2.59 & -3.63 & \\
\hline \multicolumn{2}{|c|}{$5 \%$} & -1.95 & -2.90 & -3.46 & -1.95 & -3.07 & \\
\hline \multicolumn{2}{|c|}{$10 \%$} & -1.61 & -2.59 & -3.16 & -1.61 & -2.78 & \\
\hline
\end{tabular}

\footnotetext{
corresponding critical values.

${ }^{2 /}$ All variables are expressed in natural logarithmic form.

${ }^{3 /}$ As a ratio of previous period's total external trade in goods and services.

${ }^{4 /}$ In percent of GDP.
}

${ }^{1 /}$ Null Hypothesis is unit root in all cases. The Null Hypothesis is accepted for t-statistics greater than 
Table 2. Johansen Cointegration Tests between the Real Effective Exchange Rate and the Fundamentals

(a) Cointegration between LREER and LRP_COM

\begin{tabular}{|c|c|c|c|c|}
\hline \multicolumn{5}{|c|}{ Unrestricted Cointegration Rank Test (Trace) } \\
\hline Hypothesized no. of CE(s) & Eigenvalue & Trace Statistic & $\begin{array}{l}\text { Critical } \\
\text { Value }\end{array}$ & Prob. ${ }^{1 /}$ \\
\hline None* & 0.147 & 14.960 & 15.495 & 0.060 \\
\hline At most 1 & 0.015 & 1.304 & 3.841 & 0.254 \\
\hline \multicolumn{5}{|c|}{ Unrestricted Cointegration Rank Test (Maximum Eigenvalue) } \\
\hline Hypothesized no. of CE(s) & Eigenvalue & $\begin{array}{l}\text { Maximum- } \\
\text { Eigen Statistic }\end{array}$ & $\begin{array}{l}\text { Critical } \\
\text { Value }\end{array}$ & Prob. ${ }^{1 /}$ \\
\hline None* & 0.146826 & 13.6561 & 14.2646 & 0.0622 \\
\hline At most 1 & 0.015048 & 1.30398 & 3.841466 & 0.2535 \\
\hline \multicolumn{5}{|c|}{${ }^{1 /}$ MacKinnon-Haug-Michelis (1999) p-values } \\
\hline \multicolumn{5}{|c|}{$*$ Rejection of the hypothesis at $10 \%$ level. } \\
\hline
\end{tabular}

\begin{tabular}{|c|c|c|c|c|}
\hline \multicolumn{5}{|c|}{ Unrestricted Cointegration Rank Test (Trace) } \\
\hline \multirow[b]{2}{*}{ Hypothesized no. of $\mathrm{CE}(\mathrm{s})$} & \multirow[b]{2}{*}{ Eigenvalue } & \multicolumn{3}{|c|}{ Critical } \\
\hline & & Trace Statistic & Value & Prob. ${ }^{1 /}$ \\
\hline None* & 0.266075 & 46.37389 & 47.85613 & 0.0684 \\
\hline At most 1 & 0.120272 & 19.76994 & 29.79707 & 0.4385 \\
\hline At most 2 & 0.071095 & 8.749647 & 15.49471 & 0.3891 \\
\hline At most 3 & 0.027603 & 2.407229 & 3.841466 & 0.1208 \\
\hline \multicolumn{5}{|c|}{ Unrestricted Cointegration Rank Test (Maximum Eigenvalue) } \\
\hline Hypothesized no. of CE(s) & Eigenvalue & $\begin{array}{c}\text { Maximum- } \\
\text { Eigen Statistic }\end{array}$ & $\begin{array}{l}\text { Critical } \\
\text { Value }\end{array}$ & Prob. ${ }^{1 /}$ \\
\hline None* & 0.266075 & 26.60395 & $5 \quad 27.58434$ & 0.0663 \\
\hline At most 1 & 0.120272 & 11.02029 & 21.13162 & 0.6453 \\
\hline At most 2 & 0.071095 & 6.342418 & 14.2646 & 0.5697 \\
\hline At most 3 & 0.027603 & 2.407229 & 3.841466 & 0.1208 \\
\hline \multicolumn{5}{|c|}{${ }^{1 /}$ MacKinnon-Haug-Michelis (1999) p-values } \\
\hline \multicolumn{5}{|c|}{ *Rejection of the hypothesis at $10 \%$ level. } \\
\hline \multicolumn{5}{|l|}{ (c) Cointegration restriction tests } \\
\hline & \multicolumn{2}{|l|}{ Restricted log- } & \multicolumn{2}{|l|}{ Degrees of } \\
\hline Null hypothesis & likehood & LR Statistic & Freedom & Probability \\
\hline Coefficient on LRP_COM is zero & 650.3344 & 1.920112 & 1 & 0.1658 \\
\hline Coefficient on LPROD is zero $* *$ & 649.2462 & 4.096616 & 1 & 0.0430 \\
\hline Coefficient on LGCN is zero*** & 645.7832 & 11.02264 & 1 & 0.0009 \\
\hline \multicolumn{5}{|c|}{$* *$ Rejection of the hypothesis at $5 \%$ level. } \\
\hline \multicolumn{5}{|c|}{$* * *$ Rejection of the hypothesis at $1 \%$ level. } \\
\hline
\end{tabular}

\begin{tabular}{|c|c|c|c|c|}
\hline Hypothesized no. of $\mathrm{CE}(\mathrm{s})$ & Eigenvalue & Trace Statistic & $\begin{array}{l}\text { Critical } \\
\text { Value }\end{array}$ & Prob. ${ }^{1 /}$ \\
\hline None $* * *$ & 0.236197 & 37.57606 & 29.79707 & 0.0052 \\
\hline At most 1 & 0.103207 & 14.40381 & 15.49471 & 0.0725 \\
\hline At most $2 * *$ & 0.056874 & 5.035806 & 3.841466 & 0.0248 \\
\hline \multicolumn{5}{|c|}{ Unrestricted Cointegration Rank Test (Maximum Eigenvalue) } \\
\hline Hypothesized no. of $\mathrm{CE}(\mathrm{s})$ & Eigenvalue & $\begin{array}{l}\text { Maximum- } \\
\text { Eigen Statistic }\end{array}$ & $\begin{array}{l}\text { Critical } \\
\text { Value }\end{array}$ & Prob. ${ }^{1 /}$ \\
\hline None $* *$ & 0.236197 & 23.17225 & 21.13162 & 0.0255 \\
\hline At most 1 & 0.103207 & 9.368004 & 14.2646 & 0.2568 \\
\hline At most $2 * *$ & 0.056874 & 5.035806 & 3.841466 & 0.0248 \\
\hline
\end{tabular}

\section{CInternational Monetary Fund. Not for Redistribution}


Table 2. Johansen Cointegration Tests between the Real Effective Exchange Rate and the Fundamentals (concluded)

(e) LREER, LRP_COM, LPROFIT, and LNIR

\begin{tabular}{|c|c|c|c|c|}
\hline \multicolumn{5}{|c|}{ Unrestricted Cointegration Rank Test (Trace) } \\
\hline $\begin{array}{l}\text { Hypothesized } \\
\text { no. of } \mathrm{CE}(\mathrm{s})\end{array}$ & Eigenvalue & Trace Statistic & $\begin{array}{l}\text { Critical } \\
\text { Value }\end{array}$ & Prob. ${ }^{1 /}$ \\
\hline None $* *$ & 0.3317 & 54.1336 & 47.8561 & 0.0115 \\
\hline At most 1 & 0.1118 & 20.2804 & 29.7971 & 0.4040 \\
\hline At most 2 & 0.0752 & 10.3257 & 15.4947 & 0.2565 \\
\hline At most $3 *$ & 0.0438 & 3.7582 & 3.8415 & 0.0525 \\
\hline \multicolumn{5}{|c|}{ Unrestricted Cointegration Rank Test (Maximum Eigenvalue) } \\
\hline $\begin{array}{l}\text { Hypothesized } \\
\text { no. of CE(s) }\end{array}$ & Eigenvalue & $\begin{array}{l}\text { Maximum- } \\
\text { Eigen Statistic }\end{array}$ & $\begin{array}{l}\text { Critical } \\
\text { Value }\end{array}$ & Prob. ${ }^{1 /}$ \\
\hline None $* * *$ & 0.331698 & 33.85326 & 27.58434 & 0.0069 \\
\hline At most 1 & 0.111755 & 9.954619 & 21.13162 & 0.7489 \\
\hline At most 2 & 0.075207 & 6.567558 & 14.2646 & 0.5415 \\
\hline At most $3^{*}$ & 0.043754 & 3.758178 & 3.841466 & 0.0525 \\
\hline \multicolumn{5}{|c|}{$\begin{array}{l}{ }^{1 /} \text { MacKinnon-Haug-Michelis (1999) p-values } \\
\text {. }\end{array}$} \\
\hline \multicolumn{5}{|c|}{ * Denotes rejection of the hypothesis at $10 \%$ level. } \\
\hline \multicolumn{5}{|c|}{ ** Denotes rejection of the hypothesis at $5 \%$ level. } \\
\hline \multicolumn{5}{|c|}{$* * *$ Denotes rejection of the hypothesis at $1 \%$ level. } \\
\hline
\end{tabular}

Unrestricted Cointegration Rank Test (Trace) Hypothesized Eigenvalue Trace Statistic Critical Prob. ${ }^{1 /}$ no. of $\mathrm{CE}(\mathrm{s})$

None $* * *$ Value

$\begin{array}{lllll}\text { At most } 1 & 0.003496 & 0.294206 & 3.841466 & 0.5875\end{array}$

Unrestricted Cointegration Rank Test (Maximum Eigenvalue) Hypothesized Maximum- Critical no. of $\mathrm{CE}(\mathrm{s})$ Eigenvalue Eigen Statistic Value Prob. ${ }^{1 /}$

$\begin{array}{lllll}\text { None } * * * & 0.247573 & 23.89393 & 14.2646 & 0.0011\end{array}$

\begin{tabular}{lllll} 
At most 1 & 0.003496 & 0.294206 & 3.841466 & 0.5875 \\
\hline
\end{tabular}

${ }^{1 /}$ MacKinnon-Haug-Michelis (1999) p-values

*** Denotes rejection of the hypothesis at $1 \%$ level.

(g) LPROFIT and LRP_COM

\begin{tabular}{lrrrr}
$\begin{array}{l}\text { Unrestricted } \\
\text { Hypothesized }\end{array}$ & $\begin{array}{c}\text { Eigenvalion Rank Test (Trace) } \\
\text { no. of CE(s) }\end{array}$ & \multicolumn{5}{c}{ Trace Statistic Critical } & Prob. ${ }^{1 /}$ \\
nalue & \multicolumn{4}{c}{ Valur } \\
None ** & 0.155422 & 16.85422 & 15.49471 & 0.031 \\
At most 1 & 0.031229 & 2.665094 & 3.841466 & 0.1026
\end{tabular}

Unrestricted Cointegration Rank Test (Maximum Eigenvalue)

\begin{tabular}{|c|c|c|c|c|}
\hline $\begin{array}{l}\text { Hypothesized } \\
\text { no. of CE(s) }\end{array}$ & Eigenvalue & $\begin{array}{l}\text { Maximum- } \\
\text { Eigen Statistic }\end{array}$ & $\begin{array}{l}\text { Critical } \\
\text { Value }\end{array}$ & Prob. ${ }^{1 /}$ \\
\hline None* & 0.155422 & 14.18913 & 14.2646 & 0.0514 \\
\hline At most 1 & 0.031229 & 2.665094 & 3.841466 & 0.1026 \\
\hline
\end{tabular}


Table 3. Gregory-Hansen Test for Cointegration with Regime Shift: annual sample (1970-2013) ${ }^{1 /}$

(a) LREER and LRP_COM

\begin{tabular}{lccccc}
\hline & Test & & \multicolumn{3}{c}{ Asymptotic critical values } \\
\cline { 4 - 6 } & statistic & Shift year & $1 \%$ & $5 \%$ & $10 \%$ \\
\hline ADF & $-4.70^{*}$ & 1987 & -5.47 & -4.95 & -4.68 \\
$\mathrm{Z}_{\mathrm{t}}$ & $-4.75^{*}$ & 1987 & -5.47 & -4.95 & -4.68 \\
$\mathrm{Z}_{\mathrm{a}}$ & -30.34 & 1987 & -57.17 & -47.04 & -41.85 \\
\hline
\end{tabular}

(b) LREER and All Fundamentals ${ }^{2 /}$

\begin{tabular}{lccccc}
\hline & Test & & \multicolumn{3}{c}{ Asymptotic critical values } \\
\cline { 3 - 6 } & statistic & Shift year & $1 \%$ & $5 \%$ & $10 \%$ \\
\hline ADF & $-7.08 * * *$ & 1988 & -6.92 & -6.41 & -6.17 \\
$Z_{\mathrm{t}}$ & $-6.24 *$ & 1989 & -6.92 & -6.41 & -6.17 \\
$Z_{\mathrm{a}}$ & -30.34 & 1989 & -90.35 & -78.52 & -75.56 \\
\hline
\end{tabular}

${ }^{1 /}$ The null hypothesis is 'no cointegration'.

${ }^{2 /}$ Includes LRP_COM, LPROD, LGCN and LNFL.

*Null hypothesis regected at $10 \%$ significance level.

$* * *$ Null hypothes is regected at $1 \%$ significance level. 
Table 4. Estimating Non-linear Cointegrations using the

FMOLS Method: annual sample (1970-2013)

(a) LREER and LRP_COM

LREER $=\mathrm{a}(1) *$ LRP_COM+a(2)*LRP_COM $\times \mathrm{RS} 1987+\mathrm{a}(3)$

\begin{tabular}{llll}
\hline Coefficient $^{1 /}$ & Coefficient & Standard error & Probability \\
\hline $\mathrm{a}(1)$ & -0.26 & 0.12 & 0.0349 \\
$\mathrm{a}(2)$ & 0.27 & 0.02 & 0.0000 \\
$\mathrm{a}(3)$ & 4.59 & 0.54 & 0.0000 \\
\hline
\end{tabular}

(b) LREER and All Fundamentals

LREER $=$

b(1)*LRP_COM+b(2)*LRP_COM $\times$ RS1988+b(3)*LGCN+b(4)*LGCN

$\times$ RS1988 + b(5)*LPROD + b(6)*LPROD $\times$ RS1988 + b(7)*LNFL + $\mathrm{b}(8) *$ TRADE_OPEN $+\mathrm{b}(9)$

\begin{tabular}{llll}
\hline Variable $^{2 /}$ & Coefficient & Standard error & Probability \\
\hline $\mathrm{b}(1)$ & -0.16 & 0.01 & 0.0000 \\
$\mathrm{~b}(2)$ & 0.19 & 0.00 & 0.0000 \\
$\mathrm{~b}(3)$ & -0.44 & 0.03 & 0.0000 \\
$\mathrm{~b}(4)$ & 0.63 & 0.04 & 0.0000 \\
$\mathrm{~b}(5)$ & -0.76 & 0.04 & 0.0000 \\
$\mathrm{~b}(6)$ & 0.95 & 0.04 & 0.0000 \\
$\mathrm{~b}(7)^{3 /}$ & -0.06 & 0.01 & 0.0000 \\
$\mathrm{~b}(8)^{3 / 4 /}$ & 0.52 & 0.01 & 0.0000 \\
$\mathrm{~b}(9)$ & 4.01 & 0.04 & 0.0000 \\
\hline
\end{tabular}

(c) Wald coefficient restriction tests

\begin{tabular}{llll}
\hline Null hypothesis & value & t-statistic & Probability \\
\hline $\mathrm{a}(1)+\mathrm{a}(2)=0$ & 0.01 & 0.11 & 0.9100 \\
$\mathrm{~b}(1)+\mathrm{b}(2)=0$ & 0.03 & 2.95 & 0.0057 \\
$\mathrm{~b}(3)+\mathrm{b}(4)=0$ & 0.19 & 9.26 & 0.0000 \\
$\mathrm{~b}(5)+\mathrm{b}(6)=0$ & 0.19 & 8.62 & 0.0000 \\
\hline
\end{tabular}

${ }^{1 /}$ RS1987 refers to dummy for regime shift in 1987, identified by the Gregory-Hansen test (Appendix Table 3a).

${ }^{2 /}$ RS1988 refers to dummy for regime shift in 1988, identified by the Gregory-Hansen test (Appendix Table 3b).

${ }^{3 /}$ LNFL and TRADE_OPEN (dummy for trade openness) show no change in the sign of their coefficients when interacted with RS1988. As a result, they are included without interactions.

4/ TRADE_OPEN was not included in the cointegration test in Appendix Table $3 b$ since the Gregory-Hansen test does not allow for more than four right hand side variables and dummy variables. 
Table 5. Empirical Evidence on Commodity Currency

\begin{tabular}{|c|c|c|c|c|c|}
\hline Author/s (year) & Country/ies & Sample & Method & $\begin{array}{l}\text { Elasticity on commodity } \\
\text { prices }\end{array}$ & $\begin{array}{l}\text { Definition of } \\
\text { commodity prices }\end{array}$ \\
\hline $\begin{array}{l}\text { Chen and Rogoff } \\
\text { (2003) }\end{array}$ & $\begin{array}{l}\text { Australia, Canada, New } \\
\text { Zealand }\end{array}$ & $\begin{array}{l}\text { Quarterly: } \\
\text { year varies }\end{array}$ & $\begin{array}{l}\text { Time Series } \\
\text { cointegration }\end{array}$ & $\begin{array}{l}\text { Australia (0.4), Canada (0.4), and } \\
\text { New Zealand (0.6) }\end{array}$ & $\begin{array}{l}\text { Real commodity } \\
\text { prices }\end{array}$ \\
\hline Cashin et al (2004) & $\begin{array}{l}58 \text { commodity exporting } \\
\text { countries, including Peru }\end{array}$ & $\begin{array}{l}\text { Monthly: } \\
\text { 1980-2002 }\end{array}$ & $\begin{array}{l}\text { Time Series } \\
\text { cointegration }\end{array}$ & $\begin{array}{l}\text { Median=0.4. TOT not important } \\
\text { for Peru. }\end{array}$ & $\begin{array}{l}\text { Real commodity } \\
\text { prices }\end{array}$ \\
\hline $\begin{array}{l}\text { Ferreyra and Salas } \\
(2006)\end{array}$ & Peru & $\begin{array}{l}\text { Quarterly: } \\
\text { 1980-2005 }\end{array}$ & $\begin{array}{l}\text { Time series } \\
\text { cointegration }\end{array}$ & 0.3 & TOT \\
\hline Montiel (2007) & $\begin{array}{l}\text { Argentina, Bolivia, } \\
\text { Brazil, Chile, Paraguay, } \\
\text { Uruguay }\end{array}$ & $\begin{array}{l}\text { Annual: } \\
\text { 1969-2005 }\end{array}$ & $\begin{array}{l}\text { Time series } \\
\text { cointegration }\end{array}$ & $\begin{array}{l}\text { TOT important only for } \\
\text { Argentina (1.7), Bolivia (0.6), } \\
\text { and Uruguay(0.6) }\end{array}$ & TOT \\
\hline $\begin{array}{l}\text { Iossifov and } \\
\text { Loukoianova (2007) }\end{array}$ & Ghana & $\begin{array}{l}\text { Quarterly: } \\
\text { 1984-2006 }\end{array}$ & $\begin{array}{l}\text { Time series } \\
\text { cointegration }\end{array}$ & 0.4 & $\begin{array}{l}\text { Real commodity } \\
\text { prices }\end{array}$ \\
\hline Astorga (2012) & $\begin{array}{l}\text { Argentina, Brazil, Chile, } \\
\text { Colombia, Mexico, } \\
\text { Venezuela }\end{array}$ & $\begin{array}{l}\text { Annual: } \\
\text { 1900-2000 }\end{array}$ & $\begin{array}{l}\text { Time series } \\
\text { cointegration }\end{array}$ & $\begin{array}{l}\text { Argentina (0.4), Brazil }(0.2) \text {, } \\
\text { Chile (0.1), Colombia (0.4), } \\
\text { Mexico (not significant), } \\
\text { Venezuela (0.1) }\end{array}$ & TOT \\
\hline Coudert et al (2011) & 52 commodity exporters & $\begin{array}{l}\text { Annual: } \\
\text { 1980-2007 }\end{array}$ & $\begin{array}{l}\text { Panel } \\
\text { cointegration }\end{array}$ & 0.4 & $\begin{array}{l}\text { Real commodity } \\
\text { prices }\end{array}$ \\
\hline Boudart (2012) & $\begin{array}{l}42 \text { commodity dependent } \\
\text { countries }\end{array}$ & $\begin{array}{l}\text { Monthly: } \\
\text { 1980-2009 }\end{array}$ & $\begin{array}{l}\text { Panel } \\
\text { cointegration }\end{array}$ & 0.2 & $\begin{array}{l}\text { Real commodity } \\
\text { prices }\end{array}$ \\
\hline Ricci et al (2013) & $\begin{array}{l}48 \text { industrial and } \\
\text { emerging countries }\end{array}$ & $\begin{array}{l}\text { Annual: } \\
\text { 1980-2004 }\end{array}$ & $\begin{array}{l}\text { Panel } \\
\text { cointergration }\end{array}$ & $\begin{array}{l}\text { Advanced countries }(0.8) \\
\text { Emerging markets }(0.5)\end{array}$ & $\begin{array}{l}\text { Real commodity } \\
\text { prices }\end{array}$ \\
\hline Phillips et al (2013) & $\begin{array}{l}40 \text { advanced and } \\
\text { emerging countries }\end{array}$ & $\begin{array}{l}\text { Annual: } \\
\text { 1990-2010 }\end{array}$ & $\begin{array}{l}\text { Panel OLS(fixed } \\
\text { effect) }\end{array}$ & 0.1 & $\begin{array}{l}\text { Real commodity } \\
\text { prices }\end{array}$ \\
\hline
\end{tabular}




\section{APPENDIX Figure}

Peru: The Real Effective Exchange Rate and the Fundamentals
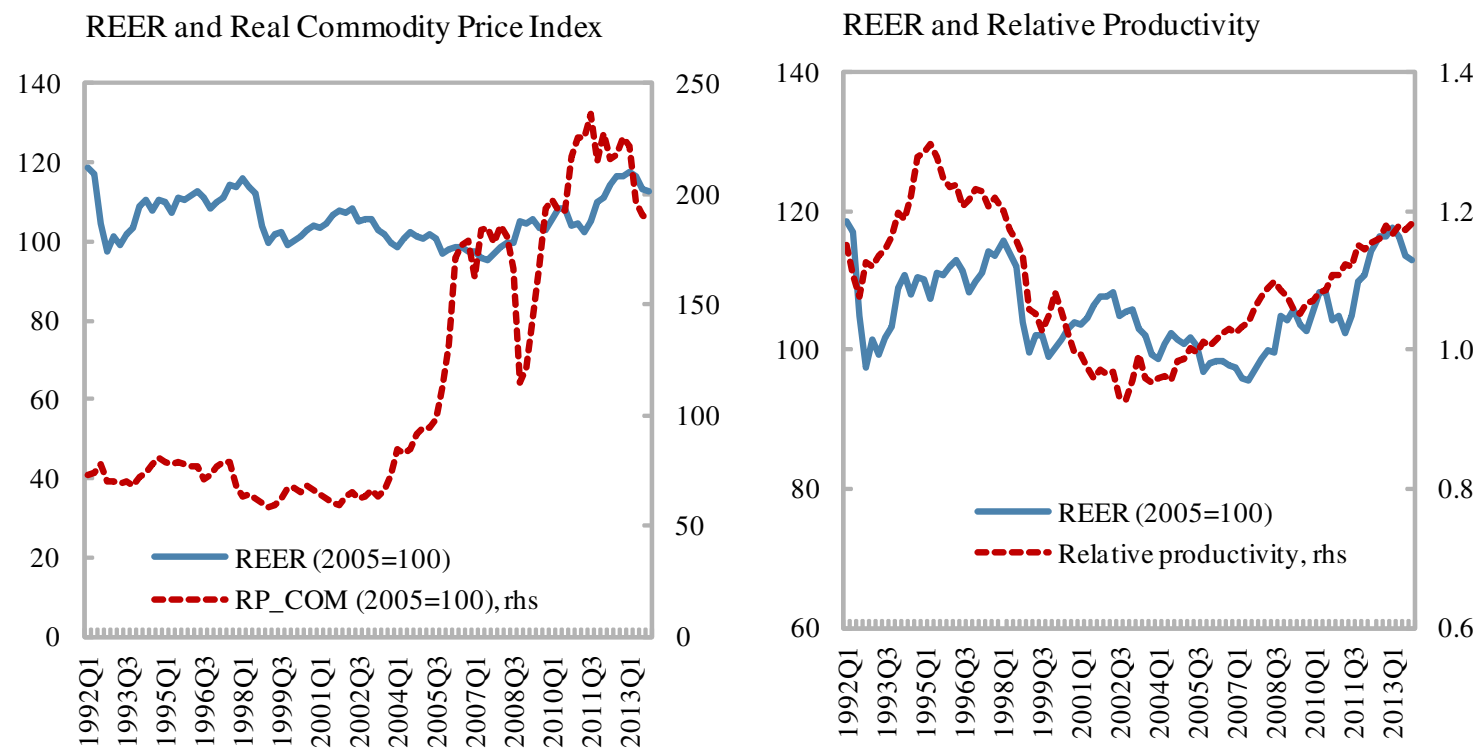

REER and Relative Government Consumption

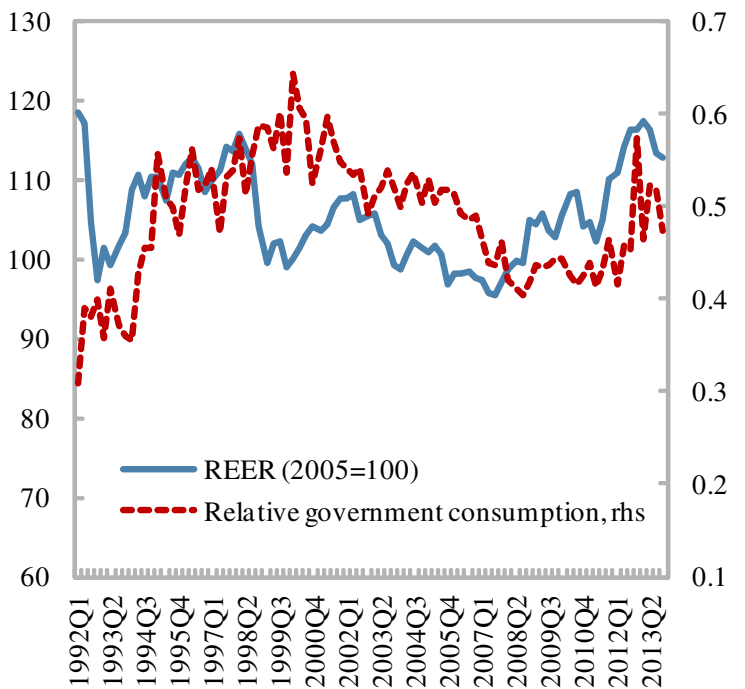

REER and Net Foreign Liability

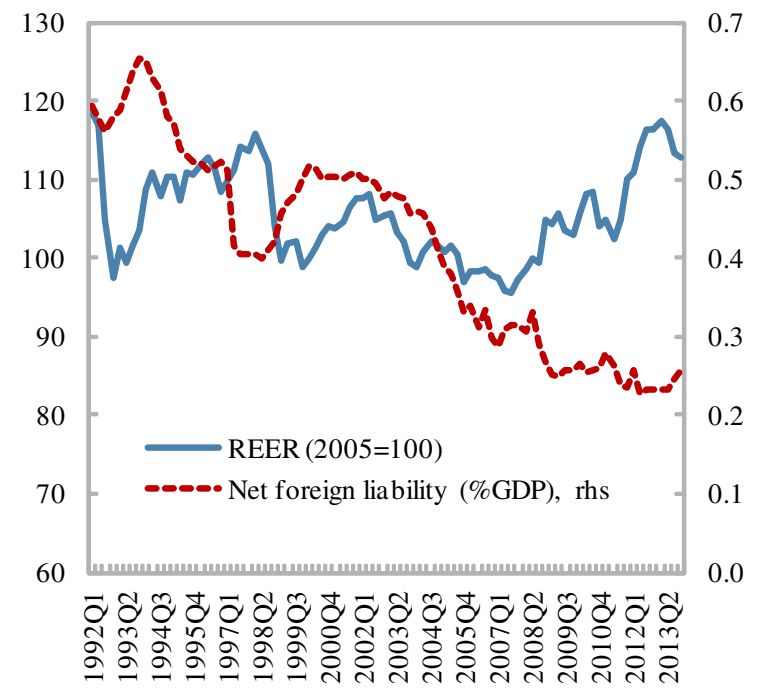

Source: BCRP, BEA, Haver, IFS, INS, WEO, and author's calculations. 


\section{REFERENCES}

Adler, Gustavo and Nicolas E., Magud, 2013, Four Decades of Terms-of-Trade Booms: SavingInvestment Patterns and a New Metric of Income Windfall, International Monetary Fund Working Paper 13/103.

Aizenman, Joshua, Sebastian Edwards, and Daniel Riera-Crichton, 2011, Adjustment Patterns to Commodity Terms of Trade Shocks: the Role of Exchange Rate and International Reserves Policies, National Bureau of Economic Research Working Paper 17692.

Astorga, Pablo, 2012, "Mean Reversion in Long-Horizon Real Exchange Rates: Evidence from Latin America," Journal of International Money and Finance 31, 1529-50.

Armas, Adrian and Francisco, Grippa, 2005, Targeting Inflation in a Dollarized Economy: The Peruvian Experience, Inter-American Development Bank Working Paper 538.

Armas, Adrian, Paul Castillo and Marco Vega, 2014, Inflation Targeting and Quantitative Tightening: Effects of Reserve Requirements in Peru. Banco Central de Reserva del Peru Workin Paper 2014-003.

Balassa, Bela, 1964, “The Purchasing Parity Doctrine: A Reappraisal,” Journal of Political Economics 72, No. 6, 584-96.

Bodart, V., B. Cabdelon, and J.F. Carpantier, 2012, "Real Exchange Rates in Commodity Producing Countries: A reappraisal,” Journal of International Money and Finance 31, 1485-1502.

Cashin, Paul, Luis Felipe Cespedes, and Ratna Sahay, 2004, "Commodity Currencies and the real Exchange Rate," Journal of Development Economics 75, No. 1:239-68.

Chen, Yu-chin, and Kenneth S. Rogoff, 2003, "Commodity Currencies," Journal of International Economics 60, No. 1, Special Issue: 133-60.

Coudert, Virginie, Cecile Couharde, and Valerie Mignon, 2011a, "Does Euro or Dollar Pegging Impact the real Exchange Rate? The Case of Oil and Commodity Currencies," World Economy 34, No. 9:1557-92.

Engel, Charles, 2000, "Long-run PPP may not hold After all," Journal of International Economics 57, 243-73.

Ferreyra, Jesus, and Jorge Salas, 2006, Tipo de cambio real de equilibrio en el Peru: modelos BEER y construccion de bandas de confianza, Banco Central de Reserva del Peru, Working Paper Series 2006-006.

Froot, Kenneth and Rogoff, Kenneth, 1995, "Perspectives on PPP and Long-run Real Exchange Rates," in Gene Grossman and Kenneth Rogoff, eds. (The Handbook of International Economics).

Gregory, Allan W., and Bruce E. Hansen, 1996, "Resdiual-Based Tests for Cointegration in Models with Regime Shifts," Journal of Econometrics 70, 99-126. 
Hinkle, Lawrence E. and Peter J., Montiel, 1999, Exchange Rate Misalignment and Measurement for Developing Countries, A World Bank Research Publication. New York: Oxford University Press.

Iossifov, Plamen and Elena Loukoianova, 2007, Estimation of a Behavioral Equilibrium Exchange Rate Model for Ghana, IMF Working Paper 07/155.

Meese, Richard A. and Rogoff, Kenneth, 1983, "Empirical Exchange rate Models of the Seventies: do they fit out of Sample," Journal of International Economics 14, 3-24.

Montiel, Peter J, 2007, Equilibrium Real Exchange Rates, Misalignment and Competitiveness in the Southern Cone, CEPAL macroeconomia del desarrollo Serie 62.

Phillips, Steven, Luis Catão, Luca Ricci, Rudolfs Bems, Mitali Das, Julian Di Giovanni, D. Filiz Unsal, Marola Castillo, Jungjin Lee, Jair Rodriguez and Mauricio Vargas Ricci, 2013, The External Balance Assessment (EBA) Methodology, IMF Working Paper 13/272.

Luca Antonio, Gian Maria Milesi-Ferretti, and Jaewoo Lee, 2013, "Real Exchange Rates and Fundamentals: a Cross-Country Perspective," Journal of Money, Credit and Banking 45, No. 5: 845-65.

Rogoff, Kenneth, 1996, “The Purchasing Power Parity Puzzle.” Journal of Economic Literature 34, 647-68.

Rossini, Renzo, Adrian Armas, and Zenon Quispe, 2014, Global Policy Spillovers and Peru's Monetary Policy: Inflation Targeting, Foreign Exchange Intervention and Reserve Requirements, BIS Papers No 78.

Samuelson, Paul, 1964, “A Theoretical Note on Trade Problems," Review of Economics and Statistics 46, No. 2, 145-54.

Tashu, Melesse, 2014, Motives and Effectiveness of Forex Interventions: Evidence from Peru, International Monetary Fund Working Paper xxx (December--upcoming). 